\title{
The origin of the western Mediterranean basin
}

\author{
JEAN M. AUZENDE, JEAN BONNIN \\ \& JEAN L. OLIVET
}

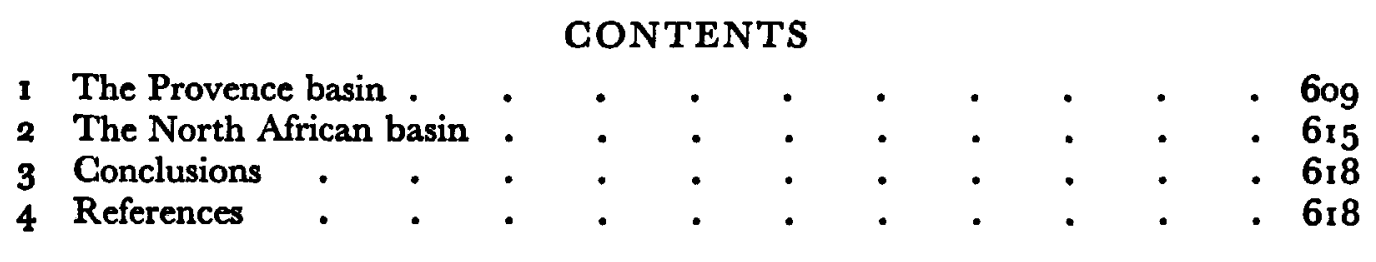

SUMMARY

- The evolution of the western Mediterranean basin is considered. The Provence basin results from the Oligocene migration of Corsica and Sardinia southeastwards. The North African basin was created by the dislocation of an 'internal zone plate' by the mechanism invoked by Karig. Lower or middle Miocene squeezing of the internal zones against the North African platform caused ejection of the flysch nappes. -

The western Mediterranean Basin has long been interpreted in two different ways. Historically it has been thought of as a remnant of a former large Alpine ocean, the Tethys, in which sedimentary material, making up part of the Alpine mountain belts, was deposited. On the other hand, a former emerged land, located in the present western Mediterranean basin, is often postulated to explain geological features observed in Sicily, North Africa, the Balearic Islands and the sw Alps (Termier I9 I ; Flandrin 1948; Kuenen 1959; Colom \& Escandell 1962; Caire 1965; Stanley \& Mutti 1968; etc.). The data gathered by the above authors rule out the Tethyan hypothesis. The western Mediterranean basin has to be created either by such processes as oceanization, or by large horizontal displacements of certain blocks so that land can emerge as late as upper Eocene times.

Refraction and magnetic anomaly studies suggest that the abyssal part (deeper than $2500 \mathrm{~m}$ ) of the western Mediterranean basin is oceanic and overlaid by a thick sedimentary sequence (Fahlquist \& Hersey 1969; Le Borgne of al. 1971; Hinz in press).

In this paper (Fig. $\mathrm{I}$ ) the northern part of the western Mediterranean basin that is surrounded by southern France, NE Spain, the Balearic Islands, Sardinia and Corsica is named the Provence basin. The basin located south of Sardinia, the Balearic Islands and Spain and north of Tunisia, Algeria and Morocco, will be called the North African basin. Several authors have supposed that the Provence basin was formed by migration of the block of Corsica and Sardinia (Argand 1924; Carey 1958; Kuenen 1959; Dubourdieu 1962; Westphal 1967; Stanley \& Mutti 1968; Ryan 1969; Smith 1971; Boccaletti \& Guazzone 1970; Alvarez 1972). Westphal (1967), Smith (197I) and Alvarez (1972) designed models in which the block reconstruction is based upon morphological criteria.

$J l$ geol. Soc. Lond. vol. 129, 1973, pp. 607-620, 6 figs., Printed in Northern Ireland. 


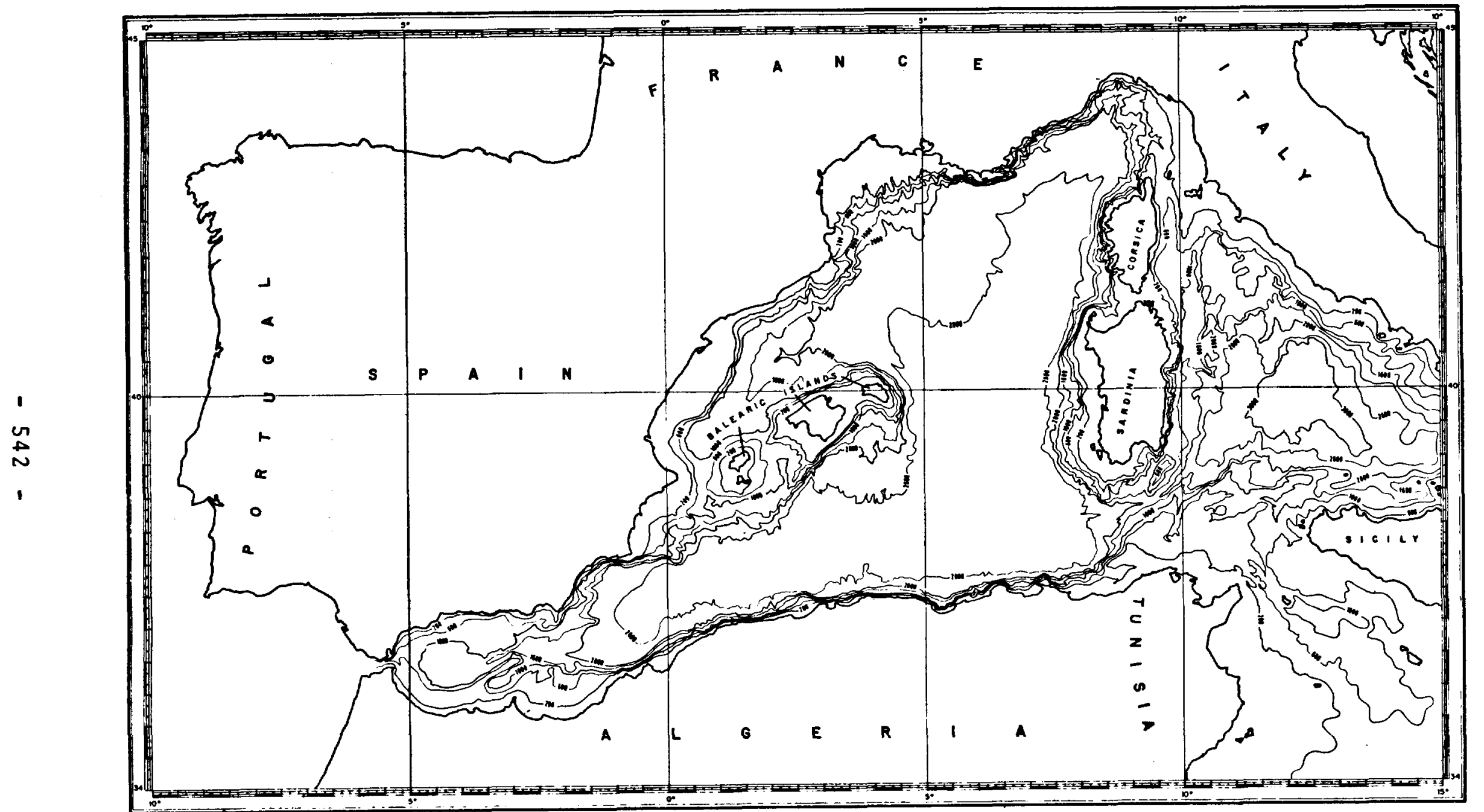

5
5
5
5
5
5
5
5

Fig. I. Bathymetric map of the western Mediterranean basin. Isobaths in metres. Redrawn by S. Monti (Centre Océanologique de Bretagne) from various sources. 


\section{The origin of the western Mediterranean basin}

For the North African basin, to our knowledge, no model has been proposed; however, Dubourdieu (1962) suggested an en echelon displacement of northern Africa toward the southwest.

We propose a double model for creating the deep basins of the western Mediterranean, with rifting of continental masses and sea-floor spreading. Two systems will be investigated: the triangular Provence basin formed by drifting of Corsica and Sardinia, and the elongated North African basin, the creation of which is related to building of the North African mountains. The proposed models are tentative and will be more thoroughly discussed elsewhere; the present study just displays the main lines of the models.

\section{The Provence basin}

The pre-drift reconstitution of the continental masses by morphological fitting leads to apparently satisfactory results. Westphal (1967) and Alvarez (1972) suggest rotation of the continental blocks so that Corsica is the eastern extension of the Provence crystalline massifs and Sardinia is an extension of the Balearic Islands, south of the Gulf of Lion. The adopted limits for the southern edge of the Sardinian continent and the $\mathrm{NE}$ Balearic block imply a large angular rotation centred on a pole in the present Ligurian sea, close to the northern tip of Corsica. Smith (1971) proposed another morphological fit in which the Balearic block was rotated back close to Spain and the Corsica-Sardinia block was just east of the reconstructed Balearic-Iberian block. Our approach is different and is based upon a careful examination of the magnetic anomalies and structural directions.

\section{(A) Magnetic ANomalies in the PRovenge basin}

A very precise aeromagnetic survey has been carried out over the northern part of the western Mediterranean (Le Mouel \& Le Borgne 1970). A series of strongly positive magnetic anomalies clearly stands out (Fig. 2) on the basin's periphery and four of them show a NW-SE preferential orientation: the Gulf of Genoa, the Straits of Bonifacio, NE of the Balearic Islands and the Gulf of Lion.

A series of points has been chosen that describes the orientation of the anomalies. These have been taken from a map of the second order vertical derivative of the reduced-to-the-pole anomalies (Le Borgne et al. 1971). It is well known that the reduced-to-the pole anomalies are better positioned above the causative sources than the simple total field anomalies and that vertical differentiating delineates the shape of the anomalies much better. 50 points have been fed through a programme that computes the best pole with which the points are aligned on small circles. This is at $54^{\circ} \mathrm{N} 24^{\circ} \mathrm{E}$ and the points describe small circles relative to this pole with a standard deviation that is less than $1 \cdot 5 \mathrm{~km}$. We interpret this pole as describing the movement of Corsica and Sardinia relative to western Europe. It is clear on Fig. 2 that many magnetic features follow small circles, especially two series of secondary magnetic extremes.

It should be realized that the directions of the magnetic anomalies are not necessarily true transform faults. Some of them could correspond to 'transform directions' as defined by Bonnin (in Le Pichon et al. 1971 1a), being intracontinental 


\section{J. M. Auzende et al.}

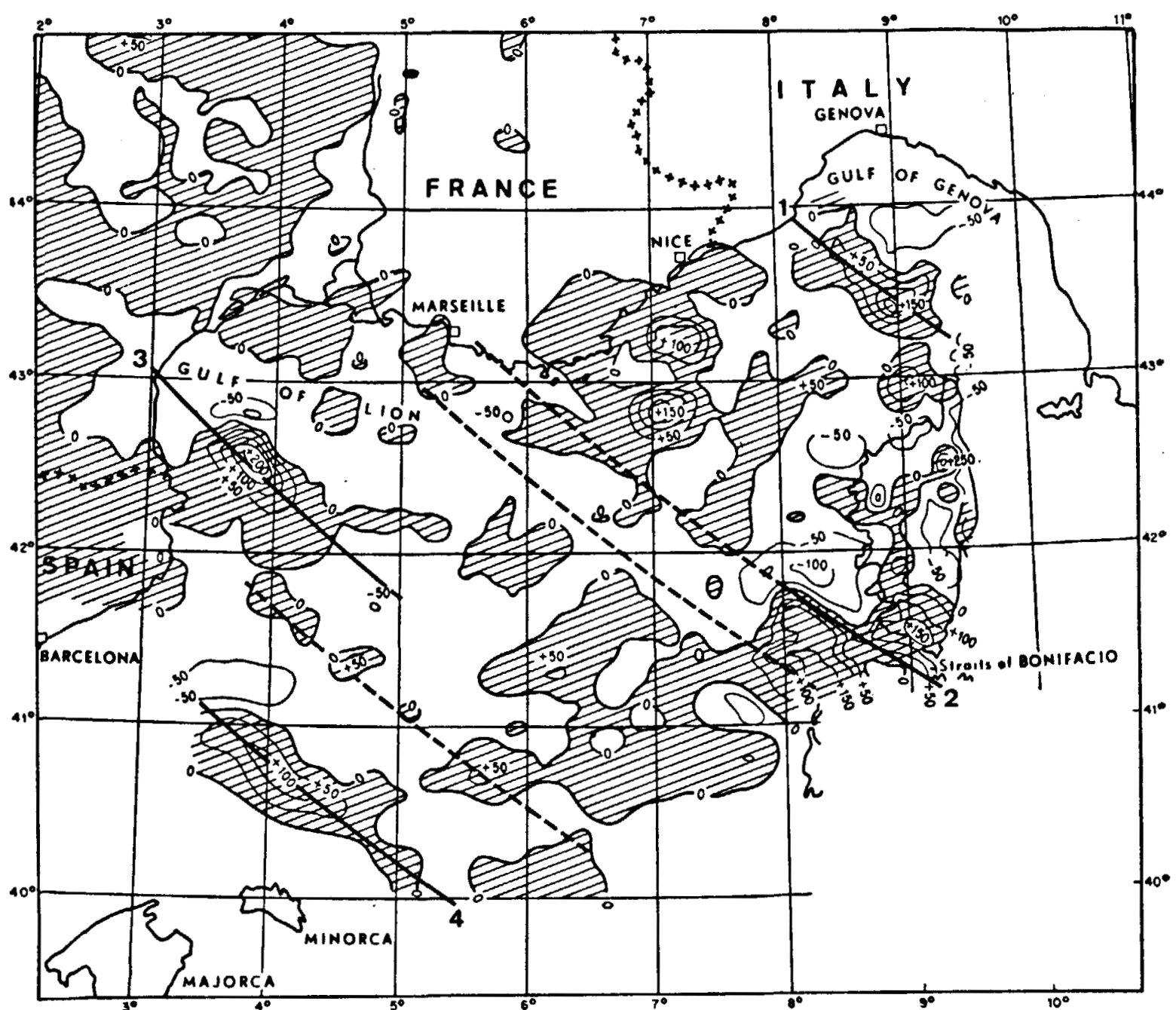

Fra. 2. Aeromagnetic anomaly sketch map (from Le Mouel \& Le Borgne 1970). Flown at an altitude of $3000 \mathrm{~m}$. Contour interval is $50 \gamma$; shaded areas are positive anomalies. Thick lines are small circles centred on a pole at $54^{\circ} \mathrm{N} 24^{\circ} \mathrm{E}$; they are superimposed on the anomalies used in computing the pole. Dashed lines are additional latitude circles which have not been used in the computations. UTM projection; origin: meridian $6^{\circ} \mathrm{E}$.

fracture zones which were created with the initial continental rifting, but later aborted and so did not evolve as transform faults. The 'transform directions' are likely to follow small circles relative to a pole of early opening, as they formed in relation to the initial stage of rifting. In addition, the Provence basin does not show any clear magnetic anomaly pattern similar to the well known pattern of the large oceanic basins in which magnetic anomalies are parallel and symmetrical to the basin's axis.

(B) STRUCTURAL FEATURES

On the continental margins, the NW-sE direction appears to be dominant from the Gulf of Genoa to the Balearic domain (Fig. 3). 
Ligurian sea. From Cape Mele, an important structure strikes Nw-se (Rehault I968); the acoustic basement is vertically offset by this structure with the lowered part on the deep basin side. Dacitic volcanics are associated with this structure (Rehault pers. comm.). No dates are available on these rocks but a similar volcanism is known east of the Maures massif and is of late-Oligocene age (Bellon \& Brousse 1971).

From the Maures Massif to Cape Mele. The margin is deeply cut by numerous canyons, three of which are particularly prominent and show linear tracks suggesting that they are structurally controlled (the Nice, Menton and San Remo canyons).

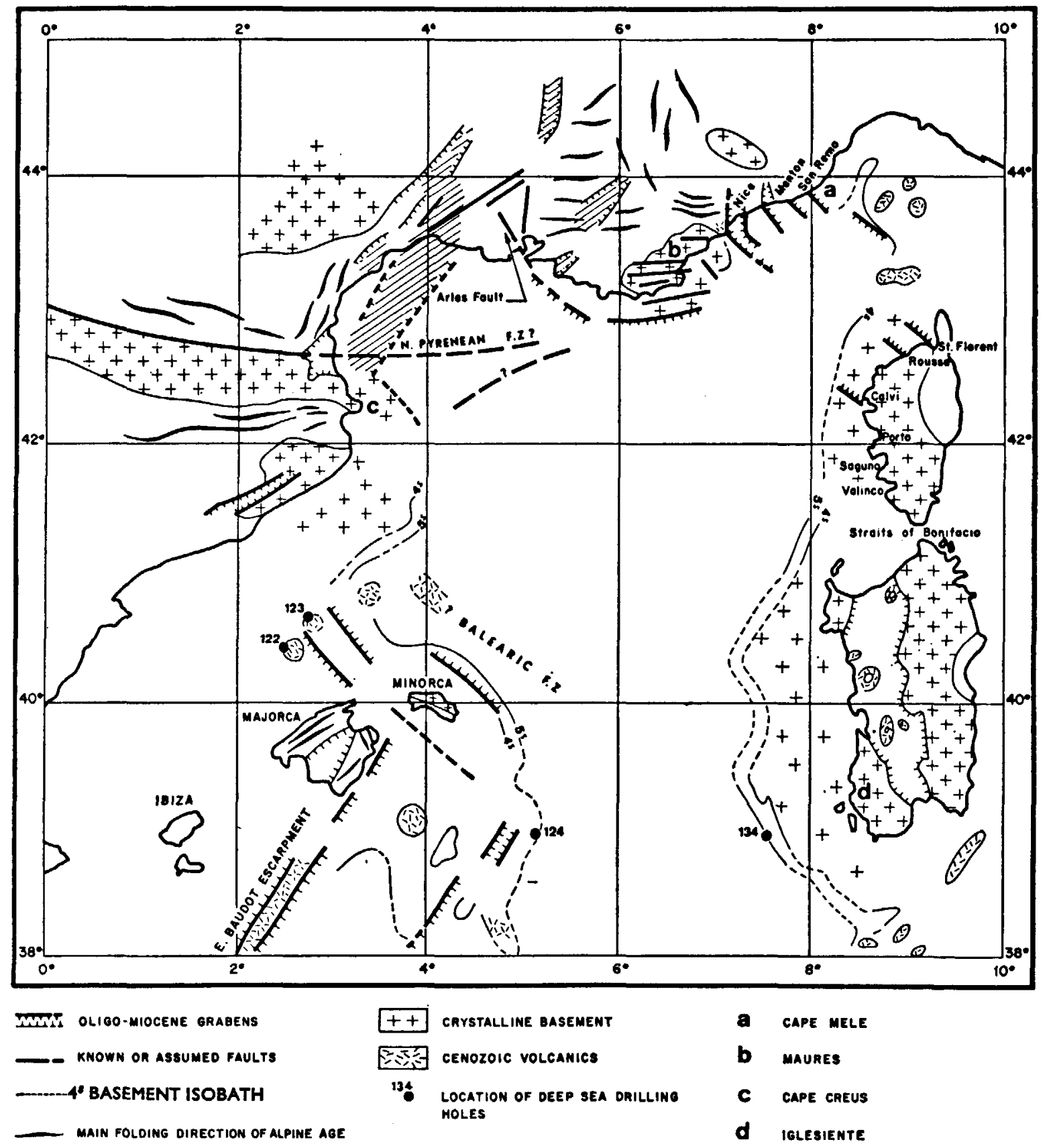

Fig. 3. Structural sketch map of the Provence basin. 


\section{J. M. Auzende et al.}

Off the Maures Massif. Again the NW-SE direction is well marked at the margin. A series of normal faults that extend the well known Arles fault to the se progressively bury the calcareous Provence rocks beneath the sedimentary cover of the Gulf of Lion. Off Cape Creus, the Nw-se direction is well marked and limits the Gulf of Lion to the west. Recent cutting of the margin by canyons seems to be controlled structurally in the same direction.

Balearic Islands. NE of Minorca, the margin is linear and strikes NW-SE. In the north Balearic basin, Auzende et al. (1972) have pointed out that a series of horsts and grabens are controlled by this direction. In addition, the shelf's morphology suggests that there are faults with the same orientation between Majorca and Minorca.

Corsica-Sardinia. The canyons off the NW margin of Corsica follow the NW-SE direction (St-Florent, Ile Rousse and Calvi canyons) as do the northern coastlines of the Gulfs of Porto, Sagone and Valinco and the hypothetical limit between Corsica and Sardinia.

Our marine data are too scarce to define any directions precisely on the Sardinian margin; however the continental limit SW of Sardinia is oriented NW-SE, and, on land, the structural limit between the mainland, Sardinia and the Iglesiente Massif could follow the same direction.

\section{(c) REgONSTRUCTION AND AGE OF OPENING}

Isobaths (in sec. of two-way travel time) of the acoustic basement are reported in Fig. 3. This acoustic basement is defined as the deepest reflector that can be traced on the profiler records (Flexotir system). This reflector is in continuity with the continental basement of which the geometry on certain margins is well known; in other words, wherever it can be traced, the acoustic basement represents the foundered extension of the continent and consequently, it will be referred to as continental basement. Its continental character has been checked by dredging south of Provence and by Glomar Challenger drill holes on the Sardinian margin.

The limit of the continent is well defined off Provence where the margin is the extension of the Maures massif crystalline basement. East of the Maures massif, the continental basement is buried beneath a Mesozoic and Tertiary sedimentary cover and its limits are poorly defined. In the Gulf of Genoa and north of Corsica, the limits of the basement are masked by important volcanics. West of Corsica, the margin is quite similar to the one off Provence; the continental slope appears, on seismic evidence to be made of hard-rocks and could mark the limit of the continent. Off Sardinia, the limits are precisely known only off the Iglesiente Massif, where Paleozoic material makes up the slope; in addition, the morphology suggests that the Sardinian continental domain extends westward so far as to double the areal extent of the island. NE of Minorca, the continental limit is well defined. In the Gulf of Lion, a very thick Tertiary sedimentary filling masks the basement.

Considering the constraints imposed by the continental limits as outlined, if Corsica and Sardinia are rotated towards the NW relative to the $54^{\circ} \mathrm{N} 24^{\circ} \mathrm{E}$ pole (Fig. 4), the possible movement of Corsica is limited to a few degrees by overlapping of the Corsican and Provencen continental limits. The same rotation 
with the same amplitude applied to Sardinia, leaves a large gap between Sardinia, the Balearic Islands and NE Spain. An additional rotation relative to the same pole, applied to Sardinia only, fills most of the gap; the latter would be filled by a hypothetical additional rotation of the sw region of Sardinia. A possible decoupling of the Iglesiente Massif from Sardinia has already been proposed on completely different grounds (Arthaud 1970).

Arguments for a Cenozoic opening of the Provence basin have been developed previously (Le Pichon et al. 197 Ib). In summarizing, many authors have shown the necessity for an emerged domain in the present basin up to Eocene times at least and foundering of the Gulf of Lion took place in Oligocene times. A generalized episode of extension occurred at this time west of the western Alps and this resulted in the formation of grabens, such as the Rhone valley and the troughs bordering Languedoc and the Gulf of Lion. It is noteworthy that the foundered structures are roughly perpendicular to the proposed movement of Corsica and Sardinia.

On the other hand, data from seismic refraction (Fahlquist \& Hersey 1969), seismic reflection (Auzende et al. 197I) and from the depth of the magnetic sources (Le Borgne et al. 197r) are consistent with a sedimentary thickness of

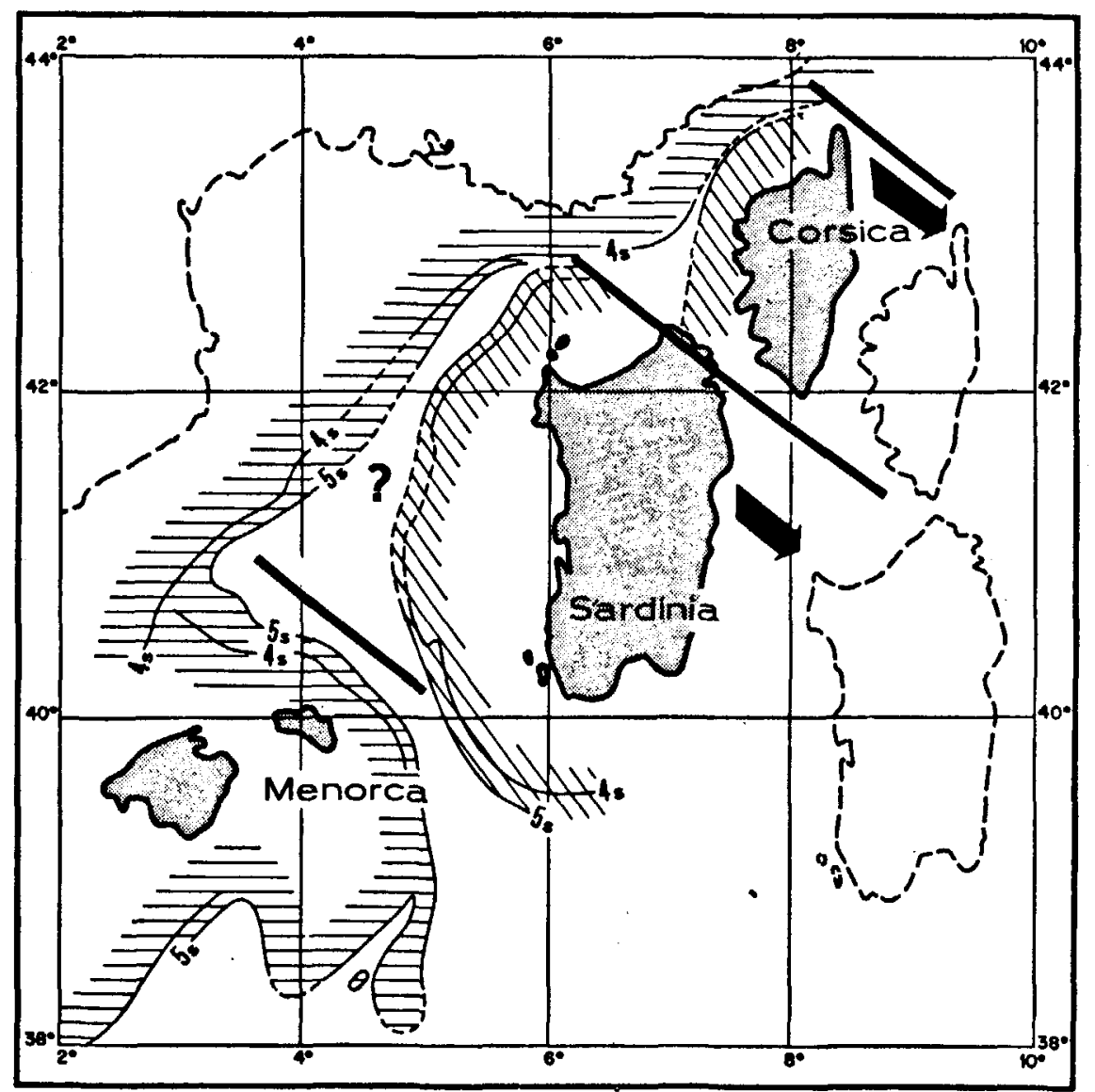

Fra. 4. Reconstitution of blocks before the creation of the Provence basin. Heavy lines are flow lines of motion. Thick arrows show the displacement. Dashed lines show the present location of Europe and Corsica and Sardinia. Shaded areas are surveyed continental basement (see text). 


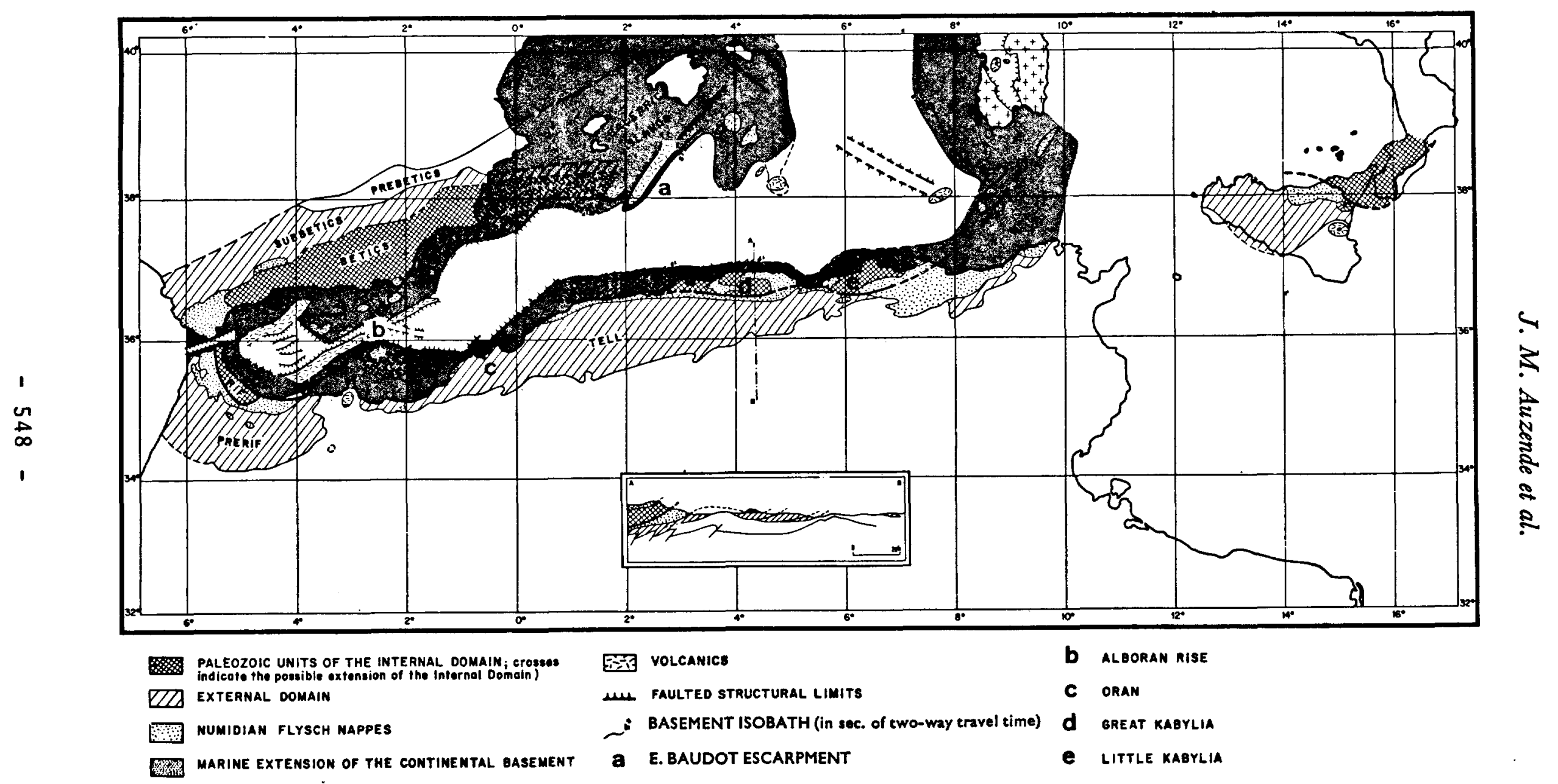

Fic. 5. Structural sketch map of the North African basin. The insert shows a sketch section across northern Africa along AB (from DurandDelga 1969). 
5-6 km. Assuming an Oligocene age, this leads to a reasonable sedimentation rate.

Considering the Provence basin to be of Oligocene age suggests attaching Corsica, Sardinia and the Balearic block to the Iberian plate in pre-Oligocene times. The north Pyrenean fault, which represents the path of the Iberian plate when the Bay of Biscay opened in the lower Cretaceous, (Le Pichon et al. 197 Ia) follows approximately the present-day border of the European continent between the Maures massif and the Gulf of Genoa. The north Pyrenean fault lay north of Corsica; hence Sardinia, Corsica and the Balearic islands travelled with Iberia in pre-Oligocene times.

\section{The North African basin}

\section{(A) SUBMARINE FEATURES}

The North African basin shows a remarkable set of morphotectonic features (Fig. 5) that are summarized below.

The Alboran basin. The NE-sw direction is well marked in all the features of the Alboran basin (Olivet et al. 1973). The most apparent feature is the Alboran rise: it is a lineament probably made of volcanic material (Giermann et al. 1968). On the magnetic map of Vogt et al. (1971), the Alboran rise is associated with a magnetic anomaly. The rise is bordered by two troughs which seem morphologically similar to the trough forming the Gibraltar Straits. In the western Alboran basin, the relief is generally linear and strikes NE-sw; the northernmost positive feature (sampled by the Glomar Challenger) (Olivet et al. 1973) could belong to a structure paralleling the Alboran rise and the feature associated with the Gibraltar Straits. To the east, the NE-sW direction controls the Oran continental margin and the margin to the east of the Balearic Islands.

The Southern margin of the Balearic Islands. The most striking feature is the Emile Baudot escarpment, south of the Balearic Islands, the SE end of which is actually a rise similar to the Alboran rise; the comparison is based on the seismic profiler results (Mauffret pers. comm.). To the NE, the Emile Baudot escarpment is well marked in the topography by a steep slope SE of Majorca, and the NE-SW direction is apparent in the general morphology of the continental margin south of the Balearic Islands (Mauffret et al. 1972).

The Sardinia-Tunisia Strait appears to be underlain by what we have defined above as continental basement (Auzende, 1971). The western limit of the continental basement is controlled by the NE-SW direction as shown by the $4 \mathrm{sec}$ isobath of the basement (Fig. 5). This 'continental boundary' is marked by a series of seamounts, the northeasternmost one being elongated in shape in the NE-SW direction. The influence of the NE-SW direction is further shown by the free-air gravity anomaly map (Allan \& Morelli 197I).

From points picked on the main features described above (the Alboran rise, the Emile Baudot Escarpment and the Sardinia-Tunisia Straits), a pole has been computed so that these features lie on small circles centred on the pole. Computations give a pole at $45^{\circ} \mathrm{N} 13.25^{\circ} \mathrm{W}$, with a standard deviation of $1.5 \mathrm{~km}$. All the structures mentioned above roughly follow small circles relative to the pole; 


\section{J. M. Auzende et al.}

this is a remarkable geometric property, that will be interpreted later on in terms of plate kinematics.

\section{(B) MODEL AND EVOLUTION}

Tectonic zoning. In the North African mountains, it is usual to distinguish:

(1) an external domain which belongs to the African platform and which has been affected by a relatively late tectonism (starting in Oligocene times in the Rif Mountains; Andrieux 1970).

(2) an internal domain formed by a series of zones made of Paleozoic and Mesozoic material. The Alpine tectonism that has been active in these zones is relatively early (Eocene in the Rif; Andrieux 1970). The internal domain shows a remarkable unity from east to west and differs drastically from the Iberian and African old blocks by its pre-Alpine tectonic and metamorphic history (DurandDelga rg69). It is likely that the internal zones of the Betic Cordillera, of the Rif, of Kabylia, Sicily and Calabria once formed a unique block (Andrieux et al. 197 I; Durand-Delga 1969 ). It is clear from the preceding discussion that a fundamental discontinuity must separate the internal domain from the external domain.

(3) a series of flysch nappes that are well known in North Africa. The sedimentary sequences of the different nappes are very complex and span from late Jurassic to lower Miocene. The nappes have been mostly emplaced in their present position by gravity sliding. The origin of the flysch on the one hand and the intervening mechanisms (other than gravity sliding) on the other hand, are still debated. Some authors favour an 'ultra' origin, that is from within the internal zones, for at least part of the flysch and a pure gravity sliding emplacement (Mattauer 1963; Caire 1965). Durand-Delga (1967) proposed that the flysch came from a domain located between the internal and external zones and the basement on which the flysch sequences have been deposited would have been

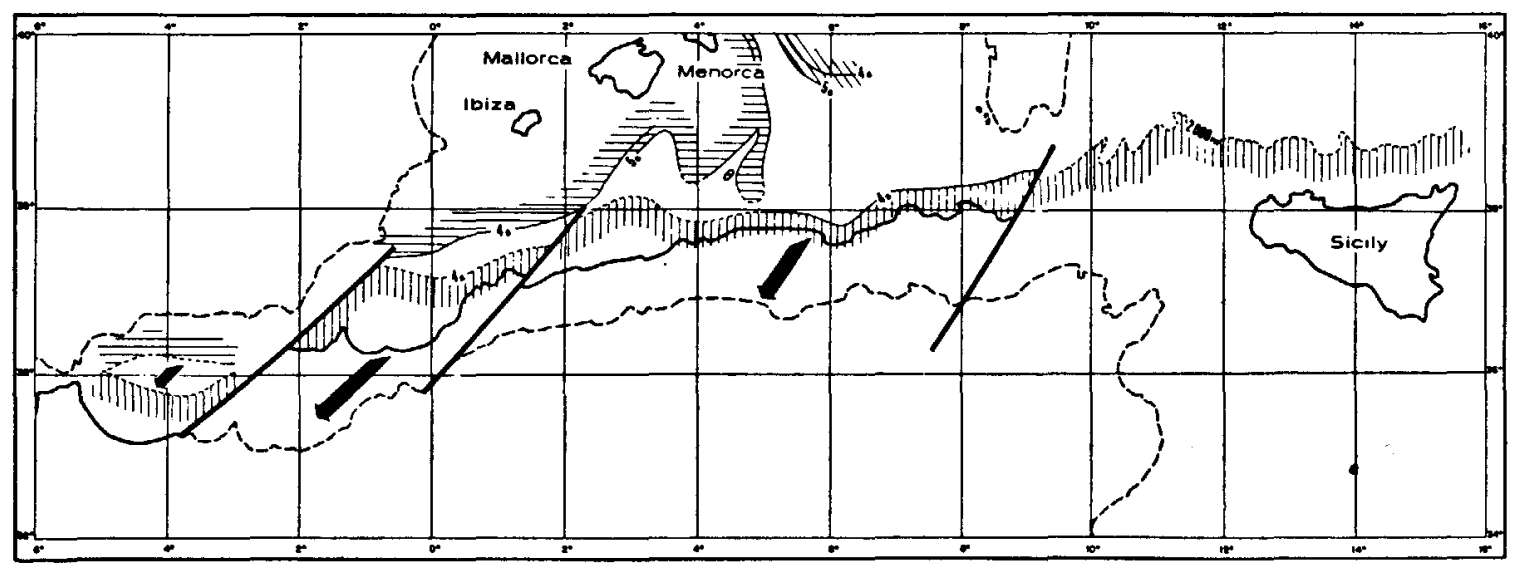

Frg. 6. Reconstruction previous to the creation of the North African basin. As the internal zone limits are poorly defined, the present shoreline has been rotated back. Heavy lines are flow lines of motion. Thick arrows show the displacement (see text). 


\section{The origin of the western Mediterranean basin}

swallowed by a giant underthrusting of the internal zones (the "succion" of Durand-Delga, the "verschluckung" of the German authors), resulting in the ejection of the flysch nappes, which would have glided later on. The major discontinuity between internal and external domains, has obviously not the same significance in the two models.

Model. In this paper we propose the following evolution. The internal zones of the sw Mediterranean belts once formed a unique block (the 'Alboran' plate of Andrieux et al. 197I). To the north of the African plate was an oceanic domain, of undetermined width but in which the different flysch series were deposited. The width of the oceanic basin was probably at least $300 \mathrm{~km}$ taking into account the palinspastic reconstructions and allowing for the shortening which is known to have occurred between the European and African plates (Pitman \& Talwani 1972). The shortening has been taken up most probably by a Benioff zone dipping to the north and underthrusting the 'internal domain plate'. According to the mechanism proposed by Karig (1971 Ia \& b) in the western Pacific region, the internal zone plate has been dislocated, an inter-arc basin appeared (the present North African basin) and several blocks moved to the sw as the Benioff zone was still active; the structural signature of the motion is, in our opinion, the set of features that are shown above as being centred on a pole. Their motion was stopped by abutting of the 'internal nuclei' against the African plate, resulting in the rising of the North African mountains and ejection of the flysch deposited in the former oceanic basin (Wezel 1970).

It is known that the latest flysch is lower Miocene in age and that its ejection is Burdigalian. In addition, andesitic volcanism has been described in the internal zones of the North African mountains, the age of which would be lower Miocene (Roubault I934; Glangeaud I952; Hilly I962; Jeremine \& Marçais I962; Glaçon 1967; Robin 1970). We interpret this volcanism as related to the Benioff zone; however volcanism is not strictly confined to zones where our interpretation is plausible, and volcanic occurrences in the external zones could be related to late fracturing produced by block movement as invoked above. Thus we assign to the present North African basin an origin of the inter-arc basin type and a Burdigalian age which is in agreement with the marine data on the sedimentary filling of the Alboran basin (Olivet et al. 1973).

It is therefore proposed that the Alboran basin results from the sw motion of part of the Alboran plate, namely the internal zones of the Rif Mountains and it is notable that in Morocco, the lateral limits of the internal domain (Straits of Gibraltar and Nkor Valley) are approximately along small circles defined above. To the east, the internal zones are absent from the emerged continent. However it is possible that they form the large plateau west of the Oran shoreline. Far into the continent, the offset of the Oran continental margin is prolonged by a volcanic alignment. The Emile Baudot escarpment appears to be homologous to the offset of the Oran margin. Finally, the North Algerian mountains result from the sw motion of the Kabylian internal nuclei. It is possible that the two Kabylia have travelled separately with a decoupling zone located presently in the Gulf of Bougie. 


\section{J. M. Auzende et al.}

\section{Conclusions}

The North African basin is an inter-arc basin and the North African belts result from the collision of the internal zones with the African plate. It is likely that this general model applies to the entire western Mediterranean basin; this is suggested by the smallness of the involved basins and by the fact that they are surrounded by important orogens. In particular, the same general tectonic setting is encountered in Calabria-Sicily and less clearly in the Betic Cordillera. However, the localization of the Benioff zone responsible for the motion of Corsica and Sardinia is not possible from our present state of knowledge.

Acknowledgements. We thank the crew and scientific party of the R.V. Jean Charcot, for their help in collecting data. We thank our colleagues of the Centre Océanologique de Bretagne for helpful discussions. Jean Mascle and Léo Pastouret critically read the manuscript. This is contribution 110 of the Département Scientifique, Centre Océanologique de Bretagne.

\section{References}

Allan, T. D. \& Moreili, C. 1971. A geophysical study of the Mediterranean. Bol. Geof. Teor. Appl. 13, 99-142.

Alvarez, W. 1972. Rotation of the Corsica-Sardinia microplate. Nature, Lond. Phys. Sci. 235, 103-105.

ANDRIEUx, J. 1970. La structure du Rif Central. Thesis, Montpellier.

-, Fontbote, J. M. \& Mattauer, M. 1971. Sur un modele explicatif de l'arc de Gibraltar. Earth Planet. Sci. Letters 12, 191-199.

Argand, E. 1924. La tectonique de l'Asie. 13th Internat. Geol. Congr. Brussels I 71-372.

ARTKAUd, F. 1970. Etude tectonique et microtectonique comparée de deux domaines hercyniens: les nappes de la Montagne Noire (France) et l'anticlinorium de l'Iglesiente (Sardaigne) Thesis, Montpellier.

Auzende, J. M. 197ı. La marge continentale tunisienne: résultats d'une étude par sismique réflexion: sa place dans le cadre tectonique de la Méditerranée occidentale. Mar. Geophys. Res. 1, 162-1 77.

—, Bonnin, J., Olivet, J. L., Pautot, G. \& Maufrret A. 1971. Upper Miocene salt layer in the western Mediterranean Basin. Nature, Lond. Phys. Sci. 230, 82-84.

- , Olivet, J. L., Maufpret A. \& Pautot, G. 1972. La dépression nord-baléare (Espagne). C. R. Acad. Sci. Paris, D, 274, 229r-2294.

Bellon, H. \& Brousse, R. 197I. L'âge oligo-miocène du volcanisme ligure. C. R. Acad. Sci. Paris 272, 3109-3III.

Boccaletti, M. \& Guazzone, G. 1970. La migrazione terziara dei bacini toscani e la rotazione dell'Appenino Settentrionale in una "zona du torzione" per deriva continentale. Mem. Soc. Geol. Italiana 9, $177-195$.

CAIRE, A. 1965. Morphotectonique de l'autochtone présaharien et de l'allochtone tellien. Rev. Géogr. Phys. Géol. Dynam. (2), 7, 267-1 75.

Garey, W. S. 1958. The orocline concept in geotectonics. Proc. Roy. Soc. Tasmania 89, 255-288.

Colom, G. \& Escandeli, B. 1962. Evolution du géosynclinal baléare. In: Livre à la mémoire du Professeur Fallot. Mém. h. Sér. Soc. Géol. Fr. r, 103-1 16.

Dubourdieu, G. 1962. Dynamique wegenerienne de l'Afrique du Nord, In: Livre à la mémoire du Professeur Fallot, Mém. h. Sér. Soc. Géol. Fr. 1, 627-644.

Durand-Delga, M. 1967. Structure and geology of the North-East Atlas. In: Guidebook to the Geology and History of Tunisia. Petrol. Expl. Soc. Lybia, Tripoli 59-83. 


\section{The origin of the western Mediterranean basin}

Durand-Delga, M. 1969. Mise au point sur la structure du ne de la Berbérie. Pub. Sero. Géol. Algérie 39, 89-131.

Fahlquist, D. A. \& Hersey, J. B. 1969. Seismic refraction measurements in the western Mediterranean Sea, Bull. Inst. Océanog. Monaco 67, $5^{2} \mathrm{pp}$.

Flandrin, J. 1948. Contribution à l'étude de stratigraphie du Nummultique algérien. Bull. Sero. Cart. Géol. Algérie lère s., 8.

Giermann, G., Pfannenstiel, M. \& Wimmenauer, W. 1968. Relations entre morphologie, tectonique et volcanisme en mer d'Alboran. C. R. somm. Soc. Geol. Fr. I $16-118$.

GLAçon, J. I967. Etude du massif volcanique de Cavallo. C.R. inèdit de la mission I966. RGP i 6 CNRS.

Glangeaud, L. I952. Les éruptions tertiaires nord-africaines et leurs relations avec la tectonique

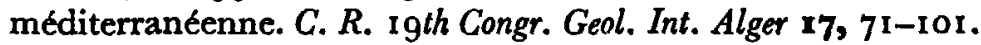

Hilly, J. 1962. Etude géologique du Massif de l'Edough et du Cap de Fer (Est Constantinois). Bull. Serv. Cart. Géol. Algérie $x 9$.

HINz, K. 1972. Results of seismic refraction investigations (project Anna) in the western Mediterranean Sea south and north of the Island Mallorca Bull. Centre Rech. Pau-SNPA 6, 405-426.

Jeremine, E. \& MARÇAIs, J. I 962. La région volcanique des Bari-Bou-Yahi. In: Livre à la mémoire du Professeur Fallot, Mém. h. Sér. Soc. Géol. Fr. 1, 43I-446.

KARIG, D. E. 1971a. Origin and development of marginal basins in the western Pacific. $J$. Geophys. Res. 76, 2542-256r.

197 rb. Structural history of the Mariana Island arc system. Geol. Soc. Am. Bull. 82, 323-344.

KueNEN, P. H. 1959. L'âge d'un bassin méditerranéen, in: Coll. Int. C.N.R.S. 83, 157-162.

Le Borgne, E., Le Mouel, J. \& Le Pichon, X. 1971. Aeromagnetic survey of southwestern Europe. Earth. Planet. Sci. Letters 12, 287-299.

Le Mouel, J. \& Le Borgne, E. 1970. Les anomalies magnétiques du Sud-Est de la France et de la Méditerranée Occidentale. C. R. Acad. Sc. Paris, D. 271, 1348-1 350.

Le Pichon, X., Bonnin, J., Francheteau, J. \& Sibuet, J. G. ig7ra. Une hypothèse d'évolution tectonique du golfe de Gascogne. in Histoire structurale du golfe de Gascogne 2; Ed. Technip. Paris, VI/I I/I-44.

—, Pautot, G., Auzende, J. M. \& Olivet, J. L. I97ıb. La Méditerranée Occidentale depuis l'Oligocène: schéma d'evolution. Earth. Planet. Sci. Letters 13, 145-152.

Mattaukr, M. 1963. Le style tectonique des chaîne tellienne et rifaine. Geol. Rundschau 53, 2968 r3.

Mauffret, A., Auzende, J. M., Olivet, J. L. \& Pautot, G. 1972. Le bloc continental baléare (Espagne). Extension et évolution. Mar. Geol. 12, 289-300.

Olivet, J. L., Pautot, G. \& Auzende, J. M. 1973. Alboran sea: structural framework. In: Initial Rep. of the Deep Sea Drilling Project 13, National Science Foundation, Washington.

Prtman, W. C. III \& Talwani, M. 1972. Sea-floor spreading in the North Atlantic. Geol. Soc. Am. Bull. 83, 6rg-646.

Rehault, J. P. 1968. Contributions à l'étude de la marge continentale au large d'Imperia et de la plaine abyssale ligure. Thesis, Paris.

RoвIN, G. 1970. Etude géodynamique du massif volcanique du cap Cavallo (El Aouana). Algérie. Thesis, Paris.

Roubault, M. 1934. Sur l'âge des éruptions acides tertiaires de la Kabylie de Collo (Département de Constantine-Algérie). C. R. Somm. Soc. Géol. Fr. $216-218$.

Ryan, W. B. F. 1969. The floor of the Mediterranean Sea, Ph.D. thesis, Columbia University, $196 \mathrm{pp}$.

Smrth, A. G. 1971. Alpine deformation and the oceanic areas of the Tethys, Mediterranean and Atlantic. Geol. Soc. Am. Bull. 82, 2039-2070.

Stanley, D. J. \& Mutri, E. I968. Sedimentological evidence for an emerged land mass in the Ligurian sea during the Palaeogene, Nature, Lond. 218, 32-36.

Termier, P. 19i1. Les problèmes de la géologie tectonique dans la Méditerranée occidentale. Rev. Gén. Sci. Pures et Appli. 8o pp.

Vogt, P. R., Higgs, R. H. \& Johnson, E. L. 1971. Hypotheses on the origin of the Mediterranean Basin: magnetic data. J. Geophys. Res. 76, 3207-3228. 


\section{J. M. Auzende et al.}

Westphal, M. 1967. Etude paléomagnétique de formations volcaniques primaires de Corse. Rapports avec la tectonique du domaine ligurien. Thesis, Strasbourg.

Wezel, F. C. 1970. Interpretazione dinamica della "eugeosinclinale meso-mediterranea". Riv. Miner. Siciliana, An. XXI, 124-126, 187-198.

Manuscript received 31 October 1972; revised manuscript received 28 December 1972; read at Marine Studies Group Meeting, February 221972. Jean Marie Auzende, Jean Bonnin \& Jean Louis Olivet, Centre Océanologique de Bretagne, Plouzane, Brest, France. 